UCRL-TR-202220

LAWRENCE LIVERMORE NATIONAL LABORATORY

\title{
Understanding Ground Motion in Las Vegas: Insights from Data Analysis and Two-Dimensional Modeling
}

A. Rodgers, H. Tkalcic, D. McCallen

February 17, 2004 


\section{Disclaimer}

This document was prepared as an account of work sponsored by an agency of the United States Government. Neither the United States Government nor the University of California nor any of their employees, makes any warranty, express or implied, or assumes any legal liability or responsibility for the accuracy, completeness, or usefulness of any information, apparatus, product, or process disclosed, or represents that its use would not infringe privately owned rights. Reference herein to any specific commercial product, process, or service by trade name, trademark, manufacturer, or otherwise, does not necessarily constitute or imply its endorsement, recommendation, or favoring by the United States Government or the University of California. The views and opinions of authors expressed herein do not necessarily state or reflect those of the United States Government or the University of California, and shall not be used for advertising or product endorsement purposes.

\section{Auspices Statement}

This work was performed under the auspices of the U.S. Department of Energy by University of California, Lawrence Livermore National Laboratory under Contract W-7405-Eng-48. 


\title{
Understanding Ground Motion in Las Vegas: Insights from Data Analysis and Two-Dimensional Modeling
}

\author{
Arthur Rodgers, Hrvoje Tkalcic \\ Earth Sciences Division, Energy and Environment Directorate \\ Lawrence Livermore National Laboratory, Livermore, CA 94551 \\ and \\ David McCallen \\ Laser Sciences Division, Engineering Directorate \\ Lawrence Livermore National Laboratory, Livermore, CA 94551
}

Report for FY03 LDRD Project 02-ERD-044

Infrastructure Response to Natural and Man-Made Ground Motions: High Performance

Computing and Distributed Sensing for Regional Scale Prediction and Response

February 17, 2004

\begin{abstract}
Summary
Seismic ground motions are amplified in low velocity sedimentary basins relative to adjacent sites on high velocity hard rock. We used historical recordings of NTS nuclear explosions and earthquake recordings in Las Vegas Valley to quantify frequencydependent basin amplification using Standard Spectral Ratios. We show that amplifications, referred to as site response, can reach a factor of 10 in the frequency band 0.4-2.0 Hz. Band-averaged site response between $0.4-2.0 \mathrm{~Hz}$ is strongly correlated with basin depth. However, it is also well known that site response is related to shallow shearwave velocity structure. We simulated low frequency $(\mathrm{f}<1 \mathrm{~Hz})$ ground motion and site response with two-dimensional elastic finite difference simulations. We demonstrate that physically plausible models of the shallow subsurface, including low velocity sedimentary structure, can predict relative amplification as well as some of the complexity in the observed waveforms. This study demonstrates that site response can be
\end{abstract}


modeled without invoking complex and computationally expensive three-dimensional structural models.

\section{Introduction}

The city of Las Vegas, Nevada is situated in the Las Vegas Valley (LVV), a broad northwest-southeast trending sedimentary basin within the southern Basin and Range province (Figure 1). LVV is underlain by recent alluvial sediments and Pleistocene lakebed sediments. The basin was formed by extensional tectonics (Wernicke et al., 1988) and is bounded on the north by the Las Vegas Valley Shear Zone (LVVSZ). Recently Langenhein et al. (2001a, 2001b) reported the geometry of the basin and the LVVSZ using gravity and seismic reflection data. They estimated the maximum depth to bedrock to be nearly $5 \mathrm{~km}$ (Figure 2C), although the definitions of geologic units and the ages of sedimentary sequences are poorly known. Significant seismic hazard in Las Vegas is indicated by its location in a deep sedimentary basin, surface alluvium deposits and the proximity of major earthquake faults. Furthermore, Las Vegas is one of the fastest growing urban areas in the United States. These factors indicate that the response of LVV to seismic ground motion deserves thorough investigation.

An early report by Davis and Lynch (1970) studied the seismic response of Las Vegas to underground nuclear explosions at the Nevada Test Site (NTS). A network of sensors was operated by Blume and Associates for the Atomic Energy Commission (AEC) and later the Department of Energy (DOE). The stations recorded these explosions at ranges of 110-180 km. Early studies of ground motion in Las Vegas used data from the Blume and Associates network. Davis and Lynch (1970) reported variable seismic response within the central section of present day Las Vegas (near Las Vegas Boulevard or "The Strip"), with amplifications of up to a factor of four in peak ground motion. However, due to a lack of data, emphasis was placed on just two sites (SQPK and SE6, Figure 2A).

Two published studies investigated seismic ground motion in LVV. Murphy and Hewlett (1975) used recordings from six NTS nuclear explosions to determine ground motion amplification within Las Vegas at 26 sites, concentrated within present-day central Las 
Vegas. Their data set was comprised of different explosions and sites than ours, but some sites are in common. The greatest amplification was observed at frequencies 0.33$0.22 \mathrm{~Hz}$ (3-4.5 s periods) where the amplification was nearly a factor of 8 . However, they used a reference site within the alluvial basin on the western side of downtown (site 801, Figure 1, Murphy and Hewlett, 1975). Ideally a reference site should be located on hard rock with little or no site response in order to obtain accurate estimates of amplification (Steidl et al., 1996). Therefore the reported amplifications could be greater or less, depending on the frequency dependent site response at site 801 . Without the access to their data set we cannot assess possible biases.

Su et al. (1998) reported ground motion and site response at nine sites in a broader area of LVV from the $\mathrm{M}_{\mathrm{W}}$ 5.6 June 291992 Little Skull Mountain (LSM) earthquake (Figure 2B shows the sites considered). That event was located on the southwestern corner of NTS with similar although slightly shorter paths compared to NTS explosions (Figure 1). They reported amplifications greater than a factor of ten at sedimentary sites in the Valley relative to the average spectral amplitude at two reference sites on the Valley's periphery. They reported maximum amplification generally occurred for periods below $1 \mathrm{~Hz}$ (Su et al., 1998, Figure 8). By using data from co-located sites, Su et al. (1998, Figure 10) showed that the analysis of Murphy and Hewlett (1975) underpredicts the site response in Las Vegas relative to a reference site on the Valley's periphery. The amplification at sites within LVV relative to a reference site outside the basin is as much as ten for frequencies below $1 \mathrm{~Hz}$. Su et al. (1998) used site amplification measurements from the LSM earthquake to predict strong motion for large (M 7.4) scenario earthquakes on the Death Valley Fault system, $150 \mathrm{~km}$ to the west of LVV and showed that accelerations from such an event can exceed $0.2 \mathrm{~g}$. The Death Valley and Furnace Creek Faults are the most likely major scenario earthquakes threatening LVV, although active faulting within LVV can not been ruled out.

This report summarizes research we performed to quantify basin amplification in Las Vegas Valley. Observed site response shows significant amplification in the basin relative to hard rock sites on the Valley's periphery. Site response curves show strong 
peaks at frequencies in the range $0.5-2.0 \mathrm{~Hz}$ with peak amplifications of up to 10 . In order to understand the observed frequency dependent amplification and constrain the basin velocity structure, we performed a number of elastic finite difference simulations using the LLNL developed $e 3 d$ code (Larsen, 2002; McCallen and Larsen, 2003). Results show that we can model site response below $1 \mathrm{~Hz}$. Models that adequately predict the site response curves require low, but realistic, shear velocities at the shallow depths.

\section{Ground Motion Data}

The data used in this study come from four sources: the Blume and Associates Seismic Safety Program network (BLUME); recordings of the June 29, 1992 Little Skull Mountain earthquake (LSM); a 2002 LSM aftershock recorded at two Advanced National Seismic System sites in Las Vegas (ANSS); and our own temporary deployment of seismometers (the Las Vegas Broadband Deployment - LVVBB). These data sets are described below.

The Blume and Associates Seismic Safety Program network was installed in the early 1960's and operated until the end of nuclear testing in 1992. Stations were located throughout southern Nevada and eastern California. Data were used primarily to understand the response of Las Vegas Basin to ground motion from nuclear explosions at NTS and the impact on buildings and structures. The network configuration and instrumentation varied through time. The data we have were recorded on three component analog strong motion accelerographs, with the specific systems evolving over time. The ground motions were digitized at 200 samples per second. We found these records to be useful in the pass band $0.2-5 \mathrm{~Hz}$ (details provide below). The instrument corrected ground motion time series from legacy NTS shots were read from their archival ASCII format and converted to Seismic Analysis Code (SAC2000) format (Goldstein et al., 2003).

All seismograms for NTS explosions recorded in LVV were previewed and P- and Swaves were picked. We collected records for 13 nuclear test explosions recorded at 29 
sites in LVV. Table 1 compiles details about the nuclear explosions taken from Springer et al. (2002). None of the explosions we collected were included in the analysis of Murphy and Hewlett, 1975). Seven events were located in the Pahute Mesa and six in the Yucca Flat areas of NTS (Figure 1). Both source regions have very similar paths from NTS to LVV. The events tend to be quite large, with teleseismic body-wave magnitudes, $\mathrm{m}_{\mathrm{b}}$, between 5.3 and 5.9. Figure 2A shows a map of the Blume and Associates sites in LVV that recorded at least one explosion.

Data were obtained for two Little Skull Mountain earthquakes on NTS. The 29 June 1992 earthquake $\left(M_{W}\right.$ 5.66) mainshock was recorded by the Blume \& Associates network and analyzed by Su et al. (1998). These sites (LSM) are shown in Figure 2B. Advanced National Seismic System (ANSS) stations operated by the Nevada Seismological Laboratory (NSL, University of Nevada, Reno) recorded the 14 June 2002 LSM aftershock $\left(M_{L}\right.$ 4.59). aftershock. The ANSS stations feature modern Kinemetrics EpiSensor acceleration sensors and $\mathrm{K} 2$ recorders (Figure 2C).

The Las Vegas Valley Broadband Deployment (LVVBB) recorded continuous weak motions from local, regional and teleseismic events between September 2002 to January 2003. The eleven stations, shown in Figure 2D, were configured to sample the northern parts of LVV along densely populated the Las Vegas Boulevard/I-15 corridor as well as to overlap sites from the BLUME and LSM data sets. Thicker sedimentary cover underlies this part of LVV. These stations featured various instruments including Guralp CMG-3ESP, Guralp 40T and Geotech S-13 sensors. Reftek 72A-08 24-bit data loggers recorded data with GPS time at 40 samples per second.

As an example of our data set, we show the north component velocity seismograms (band pass filtered 0.1-10 Hz) for the BARNWELL shot at six sites throughout the Valley (Figure 3A). Velocities at the sites SGS and CALB, on the Valley's periphery, are the smallest, while velocities within the basin are largest, particularly at RBON, LVW and S51. Note that the duration of elevated ground motion is quite long within the basin and the slower surface waves and coda tend to be longer period than the direct $\mathrm{S}$-wave. The 
long duration and amplified ground motions are common with sedimentary basins. Note that accelerations from the nuclear explosion data considered were always below 20 $\mathrm{cm} / \mathrm{s}^{2}(\sim 2 \% \mathrm{~g})$ and should be considered weak motion. Earthquake accelerations were much lower. Figure 3B shows the amplitude spectra $(0.1-10 \mathrm{~Hz})$ of the S-wave and available pre-event noise windows for both horizontal components at the same sites as Figure 3A. Signal-to-noise ratios are quite high, generally greater than 10, for all shots and sites in the band $0.2-10 \mathrm{~Hz}$. The velocities on both horizontal components have similar amplitudes. The peak amplitude occurs at around $0.2-0.4 \mathrm{~Hz}(2.5-5 \mathrm{~s})$ for these stations. The raw amplitude spectra of course contain source, path and site effects. In order to remove source and path effects and utilize both the explosion and earthquake data sets we measured site response relative to a reference site located on rock.

\section{Site Response Measurements}

Site response measurements seek to quantify the effects of shallow velocity structure and local geology at a recording site (see Kawase, 2003 for a review). It is essential to remove source and path propagation effects from observed ground motion for accurate site response measurements. Several methods have been developed to estimate site response over the last several decades. When multiple observations of an event are recorded spectral ratios have been widely used (e.g. Borcherdt, 1970; Borcherdt and Gibbs, 1976; King and Tucker, 1984; Field et al., 1992). The Standard Spectral Ratio (SSR; Borcherdt, 1970; Borcherdt and Gibbs, 1976) uses the ratio of Fourier amplitude spectra of one site relative to the reference site. Safak (1997) gives detailed analysis of site response measurement techniques when a pair of records is available, including alternatives to the SSR. Key to spectral ratio methods is the selection of the reference site, which ideally is located on hard rock and has little or no amplification relative to the motion input into the basin. The reference site must be close enough to sites of interest so that source and propagation effects are sufficiently similar and cancel when forming the spectral ratio. Studies have shown that hard rock sites can have amplification, deamplification due to tunnel and borehole effects, weathering of near-surface rock and/or topographic effects (Tucker et al., 1984; Steidl et al., 1996; Yu and Haines, 2003). Thus spectral ratios of basin sites relative to a reference site must be considered to be 
underestimates of amplification if reference site amplification is not known. If the shallow shear velocities or NHERP soil profile types (BSSC, 1995, 1998) at the sites are known, they can be used to compare basin sites with the reference site(s) (e.g. Martirosyan et al., 2003).

Another class of site response estimation techniques requiring multiple stations are the Generalized Inversion Methods. These techniques seek to simultaneously model source, propagation and site contributions to ground motion spectral amplitudes (Andrews, 1986, Boatwright et al., 1991; Hartzell, 1992). Frequency-dependent S-wave coda amplitudes have been modeled in a similar fashion (Phillips and Aki, 1986). When recordings at a reference site are not available or only single station data are available, researchers have used the Horizontal-Vertical Spectral Ratio (HVR) technique. This technique was developed to study microtremor (Nakamura; 1989) and is also referred to as the receiver function technique, (Langston, 1979). Lermo and Chavez-Garcia (1993) applied this method to earthquake ground motions. Several recent studies have compared methods (e.g. Field and Jacob, 1995; Lachet et al., 1996; Bonilla et al., 1997; Reipl et al., 1998). These studies generally report that spectral ratio and generalized inversion techniques yield similar site response estimates, but uncertainties can be different depending on the data weighting and that HVR site response estimates result in similar peak response frequencies as two- or multiple-station methods, but amplifications do not often agree.

The stations considered in this study are in relatively close proximity $(\sim 30 \mathrm{~km})$ when considering that the explosions and earthquakes are at regional epicentral distances (110$180 \mathrm{~km})$. The paths exit the source region along very similar azimuths. For such geometries, source radiation pattern and propagation effects should be common among recording stations. The data are well suited for the SSR method as originally described by Borcherdt (1970). Sites SGS/ST17 and CALB/ST06 are located outside of the deepest part of the sedimentary basin on the flanks of the Spring Mountains and Frenchman Mountain, respectively (Figure 2A). These sites consistently had the weakest ground motion for any given event (Figure 3A). Geotechnical investigations indicate that the shallow shear velocities at SGS/ST17 and CALB/ST06 are above 760 m/s (NEHRP B, 
"rock") and persist above this level for depths of 10 meters and greater (Barbara Luke, personal communication). This suggests that these sites are appropriate for reference sites. Lacking a better option, we chose to use these sites as reference sites.

Geotechnical shear wave velocities for sites in the basin show much lower values, consistent with weaker soils (velocities less than $700 \mathrm{~m} / \mathrm{s}$ in the NEHRP C and D classification).

Site response was estimated with the Standard Spectral Ratio. Waveforms were selected based on visual inspection and signal-to-noise. We extracted S-waves ground motions using windows of 60-second length with a 5\% Hanning taper. Fourier amplitude spectra were measured for the two horizontal components. We then computed the vector sum of the horizontal ground motions to compute the site response:

$$
S R_{j}^{k}(f)=\frac{S R_{j}(f)}{S R_{k}(f)}=\frac{\sqrt{\left(A_{j}^{n}(f)\right)^{2}+\left(A_{j}^{e}(f)\right)^{2}}}{\sqrt{\left(A_{k}^{n}(f)\right)^{2}+\left(A_{k}^{e}(f)\right)^{2}}}
$$

where superscripts $\mathrm{n}$ and e indicate north-south and east-west components, respectively.

Site response relative for many sites in the LVV are shown in Figures 4 and 5. For NTS explosions we used four events (BARNWELL, BODIE, COTTAGE and GASCON) and SGS as the reference site (Figure 4). For the LSM event we used ST17 (co-located at SGS) as the reference site (Figure 5A). For three regional earthquakes recorded by the LVVBB network, we used our SGS site (nearly co-located with the historical SGS site of the BLUME network). Site response in Las Vegas is quite variable, including large amplifications of 10 or more. Peaks in the curves are seen in the band $0.5-2.0 \mathrm{~Hz}$.

In order to understand the spatial variability of the site response observations, we plotted the band-averaged site response in map view with the basin depth reported by Langenheim et al. (2001) in Figure 6. These maps suggest at a correlation with basin depth for frequency bands in the range 0.4-2.0 Hz. Indeed, Figure 7 shows the bandaveraged site response versus reported basin depth and a strong linear correlation can be 
seen. Given these observations, we are left to wonder if basin depth or shallow shear wave velocities control site response in Las Vegas Valley. It is this question that we seek to answer with modeling.

\section{Modeling Site Response}

In this section, we present simulations of low frequency $(\leq 1 \mathrm{~Hz})$ ground motion and site response in Las Vegas Valley. We demonstrate that it is possible to predict the relative amplification of the seismic ground motion in the basin, as well as some of the complexity in the waveforms using only two-dimensional (2D) modeling as opposed to invoking complex and computationally intensive three-dimensional (3D) structural models.

Modeling was performed with an elastic finite-difference wave propagation code developed at LLNL by Shawn Larsen (see for example, Larsen, 2002; McCallen and Larsen, 1992). The code is a based on the elastodynamic formulation of the wave equation on a staggered grid (Madariaga, 1976; Virieux, 1986). The grid size determines the maximum frequency of the computed synthetic seismograms. As a rule 10 grid points are needed per the shortest usable wavelength. This means that in a medium with low seismic velocity the number of grid points can become large. Typical geotechnical shear wave velocities are on the order of few hundreds of $\mathrm{m} / \mathrm{s}$, which requires for a large number of grid points and a long computation time. For example, we can consider a volume described by the dimensions $150 \times 150 \times 75 \mathrm{~km}$, with the lowest shear wave velocity of $150 \mathrm{~m} / \mathrm{s}$ near the surface. For the calculations of ground motion velocities with frequencies up to $1 \mathrm{~Hz}$, each one of the three input files containing elastic parameters (compressional and shear wave velocity and density) would have about $5 \times 10^{11}$ points $(\sim 3.6 \mathrm{~Tb})$. This exceeds the memory and computational capabilities of desktop computers and requires a use of significant amount of the time of the world's most powerful parallel computing resources (McCallen and Larsen, 2003).

Our objective is to understand the origin of the amplification in the observed ground motion due to basin structure, specifically we want to model the relative amplification. 
We adopt a practical approach and seek to model the observed site response with 2D modeling, disregarding 3D effects. We simplify the complex 3D structural model by taking a plane cross-section through the 3D model. Within the crust we adopt a layered hard-rock type model in which we can embed the shape of the Langenheim et al. (2001) basin model filled with low-velocity sediments. Using the same example as above $(150 \times 75 \mathrm{~km})$, an input shear wave velocity $2 \mathrm{D}$ model file (a vertically oriented plane) would consist of $5 \times 10^{7}$ points $(0.4 \mathrm{~Gb})$.

For the simulations we used the Little Skull Mountain earthquake, which was well studied (e.g. Walter, 1993, Romanowicz et al. 1993, Harmsen 1994, Meremonte et al. 1995, Smith et al. 2001). For this event, we have the strong motion accelerometer waveforms (Figure 8). The location of the stations and the earthquake is shown in Figure 8 by yellow triangles and a star, respectively. We carefully chose a virtual profile represented with 20 equidistant fictitious stations across the basin (red triangles in Figure 9) in such a way that the locations of several of the stations correspond to those of the real stations. In this way, the synthetic site responses are suitable for comparison with the real ones, especially in relation to the basin depth.

We constructed an initial 2D velocity model, with a help of several previous studies. By taking this approach, we wanted to make sure that our model was realistic and constrained by other observations. To account for the shape of the basin, we used a model of the basin depth that was derived from gravity and seismic reflection data by Langenheim et al. (2001). To construct seismic velocities and density in our basin model, we used a combination of a compressional velocity model derived from seismic refraction studies under the Las Vegas valley (Snelson et al. 2003) and a combination of rock models from the Patton and Taylor (1984) and Bhattacharyya et al. (1999). When all three elastic parameters were not available, we used an empirical relationship between compressional wave velocity and density (Fowler 1990, page 79) and a Poisson's ratio of 0.3 to complete our initial model. The bottom part of Figure 9 shows our initial 2D shear velocity plane, containing the earthquake and the fictitious stations, whose locations with respect to the basin are plotted by triangles at the surface. 
Our initial results indicate a clear difference in site response between hard rock and basin stations, with amplifications reaching a factor 10 for the basin stations relative to the plane-layered hard rock model (Figure 9). This is in accordance with previous studies (e.g. Kawase 2003). We also notice that a secondary basin, located to the east of the Las Vegas, produces high amplifications relative to hard rock stations. It is difficult to confirm this prediction, because no stations occupied the secondary basin at the time of the Little Skull Mountain earthquake, neither currently such a station is installed.

We also investigated the sensitivity of the amplification at the basin sites to the shear and compressional velocities and density in a $250 \mathrm{~m}$ thick surface layer of the basin. Although we cannot produce the same amplitude as in the real data due to the 2-D approximation, we can compare the relative amplification between two stations with the Standard Spectral Ratio for different values of elastic parameters. In Figure 10, we illustrate the difference between two characteristic stations, located at a basin and a rock site (marked by circles in Figure 9), for shear velocities equal to 500, 750, 1000, 1250 and $1500 \mathrm{~m} / \mathrm{s}$ in the shallowest $250 \mathrm{~m}$ for frequencies up to $1 \mathrm{~Hz}$. Decreasing the surface shear velocity clearly affects the amplitude, as well as the duration of the predicted ground motion. This experiment demonstrates that in order to get realistic predictions of the ground motion, low shear wave velocities in the surface layer must be considered.

In order to understand and predict the observed site response, we computed the Standard Spectral Ratio of the radial component synthetics (basin to rock) while varying the shallow shear velocities. The predicted site response curves from a wide range of models are shown in Figure 11. Also shown is the observed site response curve from the LSM earthquake (ST10/ST17 thick black line). A strong amplification can be seen in the observed site response with a maximum near $0.6 \mathrm{~Hz}$. The $2 \mathrm{D}$ nature of the problem enabled us to easily test a relatively wide spectrum of models and determine a preferred model by trial-and-error $\mathrm{f}$ forward modeling. For example, we compared a simple steptype layer models with gradient-type multi-layer models. We found that the results are highly sensitive to the structure in the upper $200 \mathrm{~m}$ of the basin (geotechnical layer) and 
are less sensitive to the velocities in the deeper basin. In particular, we were not able to match the observed site response peak near $0.6 \mathrm{~Hz}$ with the velocities higher than $600 \mathrm{~m} / \mathrm{s}$ in the geotechnical layer. For the velocities higher than $600 \mathrm{~m} / \mathrm{s}$, we were producing the site response peaks lower in amplitude and shifted toward lower frequencies (for example, a series of green colored curves). We also found that a discrete, rather than a continuous change in velocities at the geotechnical layer boundary, predicts the observed site responses better (red and pink colored versus thin green lines). Our preferred model (shown in blue) has shear velocity equal to $600 \mathrm{~m} / \mathrm{s}$ in a $200 \mathrm{~m}$ thick geotechnical layer, and a simple 3-layer structure below. The thin pink and dark blue models result in a similar fit, yet their velocities differ by $0.5 \mathrm{~km} / \mathrm{s}$ in the deeper layers. This insensitivity of the observed site response to the structure in the deeper basin can be viewed as an uncertainty in our model. A thin black line however represents a model with a constant, low velocity in the deeper layers, and clearly shows that the increase of velocities with the depth is necessary in order to predict ground motions at the surface accurately.

\section{Conclusions}

We observed large ground motion amplification at basin sites in Las Vegas Valley relative to rock sites at the Valley's periphery. This site response can reach a factor of 10 and must be accounted for when considering earthquake or explosion ground motions in Las Vegas. A recent model of basin depth in LVV (Langenheim et al., 2001) allows us to compare site response with depth-to-basement. Site response in narrow-bands between 0.4-2.0 Hz shows a strong positive correlation with depth. Geotechnical shear wave velocities are currently being collected as part of the Las Vegas Seismic Response Project. These velocities are generally low in the central basin (shear velocities less than $700 \mathrm{~m} / \mathrm{s}$ in the NEHRP C and D soil classification) and high for rock sites on the Valley's periphery. It is expected that low velocities should result in ground motion amplification. We performed a series of 2D elastic finite difference simulations to model the observed amplification and constrain the basin shear velocity structure. We were able to successfully reproduce the observed site response for the Little Skull Mountain earthquake at a site in the basin. Our model features low shear wave velocities in the 
shallowest $200 \mathrm{~m}$ with realistic deeper basin structure. This result shows that $2 \mathrm{D}$ modeling can reproduce the observed amplification due to basin structure. However, comparison with full 3D modeling may need to be done to validate the results and assess the effect of 3D structure on ground motion.

\section{References}

Andrews, D. (1986). Objective determination of source parameters and similarity of earthquakes of differenr size, in Earthquake Source Mechanics, S. Das and C. Scholz (editors), American Geophysical Union, Washington D.C., 259-268.

Bhattacharyya, J., A. Sheehan, K. Tiampo and J. Rundle (1999). Using a genetic algorithm to model broadband regional waveforms for crustal structure in the western United States, Bull. Seism. Soc. Am., 89, 202-214.

Boatwright, J., J. Fletcher and T. Fumal (1991). A general inversion scheme for source, site and propagation characteristics using multiple recorded sets of moderate-sized earthquakes, Bull. Seism. Soc. Am., 81, 1754-1782.

Bonilla, L., J.Steidl, G. Lindley, A. Tumarkin and R. Archuleta (1997). Site amplification in the San Fernando Valley, California: Variability of site-effect estimation using the Swave, coda and H/V methods, Bull. Seism. Soc. Am., 87, 710-730.

Borcherdt, R. (1970). Effects of local geology on ground motion near San Francisco Bay, Bull. Seism. Soc. Am., 60, 29-61.

Borcherdt, R. and J. Gibbs (1976). Effects of local geologic conditions in the region on ground motion and intensities of the 1906 earthquakes, Bull. Seism. Soc. Am., 66, 467500.

Building Seismic Safety Council (1995). National Earthquake Hazard Reduction Program recommended provisions for seismic regulations for new buldings, 1994 edition, FEMA 
222A/223A, developed for the Federal Emergency Management Agency, Washington, DC.

Building Seismic Safety Council (1998). National Earthquake Hazard Reduction Program recommended provisions for seismic regulations for new buildings and other structures, 1997 Edition, FEMA 302/303, developed for the Federal Emergency Management Agency, Washington, DC.

Davis, L. and R. Lynch (1970). Seismic response characteristics at Las Vegas, Nevada, from underground nuclear detonations, NVO-1163-203, Environmental Research Corporation.

Field, E., K. Jacob and S. Hough (1992). Earthquake site response estimation: a weak motion case study, Bull. Seism. Soc. Am., 82, 2283-2307.

Field, E. and K. Jacob (1995). A comparison and test of various site-response estimation techniques, including three that are not reference-site dependent, Bull. Seism. Soc. Am., 85, 1127-1143.

Field, E., and the SCEC Phase III Working Group (2000). Accounting for site effects in probabilistic seismic hazard analysis of Southern California: Overview of the SCEC Phase III Report, Bull. Seism. Soc. Am., 90, S1-S31.

Goldstein, P., D. Dodge, M. Firpo and L. Miner (2003). SAC2000: Signal processing and analysis tools for seismologists and engineers, in International Handbook of Earthquake and Engineering Seismology, Vol. 81B, International Association of Seismology and Physics of the Earth's Interior, 1613-1614.

Harmsen, S. (1994). The Little Skull Mountain, Nevada, earthquake of June 29, 1992: aftershock focal mechanisms and tectonic stress field implications, Bull. Seism. Soc. Am., 84, 1484-1505. 
Hartzell, S. (1992). Site response estimation from earthquake data, Bull. Seism. Soc. Am., 82, 2308-2327.

Hartzell, S., S. Harmsen, A. Frankel, D. Carver, E. Cranswick, M. Meremonte and J. Michael (1998). First-generation site-response maps for the Los Angeles Region based on earthquake ground motions, Bull. Seism. Soc. Am., 88, 463-472.

Kawase, H. (2003). Site effects on strong ground motion, in International Handbook of Earthquake and Engineering Seismology, Vol. 81B, International Association of Seismology and Physics of the Earth's Interior, 1013-1030.

King, J. and B. Tucker (1984). Observed variations of earthquake motion across a sediment-filled valley, Bull. Seism. Soc. Am., 74, 137-151.

Lacet, C., D. Hatzfeld, P.-Y. Bard, N. Theodulidus, C. Papaioannuou and A. Savvaidis (1996). Site effects and microzonation in the city of Thessaloniki (Greece) comparison of different approaches, Bull. Seism. Soc. Am., 86, 1692-1703.

Langenhein, V., J. Grow, R. Jachens, G. Dixon and J. Miller (2001a). Geophysical constraints on the location and geometry of the Las Vegas Valley Shear Zone, Nevada, Tectonics, 20, 189-209.

Langenheim, V., J. Grow, R. Jachens, G. Dixon, J. Miller, S. Lundstrom and W. Page (2001b). Basin configuration beneath Las Vegas Valley, Nevada: Implications for seismic hazard evaluation, Proceedings, $36^{\text {th }}$ annual Symposium on Engineering Geology and Geotechnical Engineering, 28-30 March, 2001, B. Luke, E. Jacobson and J. Werle eds., 755-764.

Langston, C. (1979). Structure under Mount Rainer, Washington, inferred from teleseismic body waves, J. Geophys. Res., 84, 4749-4762. 
Larsen, S. (2002). Las Vegas Basin Seismic Response Project: 3-D Finite-Difference Ground Motion Simulations, EOS trans. AGU, Fall Meet. Suppl., 83 (47), Abstract S12B-1188, 2002

Lermo, J. and F. Chavez-Garcia (1993). Site effect evaluation using spectral ratios with only one station, Bull. Seism. Soc. Am., 83, 1574-1594.

Madariaga, R. (1976). On the relation between seismic moment and stress drop ni the presence of stress and strength heterogeneity, Bull. Seism. Soc. Am., 66, 639-667.

Martirosyan, A., U. Dutta, N. Biswas, A. Papageorgiou and R. Combellick (2003). Determination of site response in Anchorage, Alaska, on the basis of spectral ratio methods, Earthquake Spectra, 18, 85-104.

Mayeda, K., and W. Walter (1996). Moment, energy, stress drop and source spectra of western United States earthquakes form regional coda envelopes, J. Geophys. Res., 101, 11,195-11,208.

McCallen, D. and S. Larsen (2003). NEVADA - A simulation environment for regional estimation of ground motion and structural response, UCRL-ID-152115, Lawrence Livermore National Laboratory.

Meremonte, M, J, Gomberg and E. Cranswick (1995). Constraints on the 29 June 1992 Little Skull Mountain sequence provided by robust hypocentral estimates, Bull. Seism. Soc. Am., 85, 1039-1049.

Murphy, J. and R. Hewlett (1975). Analysis of seismic response in the city of Las Vegas, Nevada: A preliminary microzonation, Bull. Seism. Soc. Am., 65, 1575-1597.

Murphy, J. (1996). Types of seismic events and their source descriptions, E. Husebye and A. Dainty (eds.), Monitoring a Comprehensive Test Ban Treaty, 225-245, Kluwer Academic Publishers. 
Myers, S., W. Walter, K. Mayeda and L. Glenn (1999). Observations in support of Rg scattering as a source for explosion S waves: regional and local recordings of the 1997 Kazakhstan Depth of Burial Experiment, Bull. Seism. Soc. Am., 89, 544-549.

Nakamura, Y. (1989). A method for dynamic characteristics estimation of subsurface using microtremor on the ground surface, QR Railway Technical Research Institute, 30, 1.

Olsen, K. (2000). Site amplification in the Los Angeles Basin from three-dimensional model of ground motion, Bull. Seism. Soc. Am., 90, S77-S94.

Patton, H. and S. Taylor (1984). Q structure of the Basin and Range from surface waves, J. Geophys. Res., 89, 6929-6940.

Phillips, W. S. and K. Aki (1986). Site amplification of coda waves from local earthquakes in central California, Bull. Seism. Soc. Am., 76, 627-648.

Riepl, J., P.-Y. Bard, D. Hartzfeld, C. Papaioannou and S. Nechschein (1998). Detailed evaluation of site-response estimation methods across and along the sedimentary valley of Volvi (EURO-SEISTEST), Bull. Seism. Soc. Am., 88, 488-502.

Romanowicz, B., D. Dreger, M. Pasyanos and R. Uhrhammer (1993). Monitoring of strain release in central and northern California using broadband data, Geophys. Res. Lett., 20, 1643-1646.

Safak, E. (1997). Models and methods to characterize site amplification from a pair of records, Earthquake Spectra, 13, 97-129. 
Smith, K., J. Brune, D. dePolo, M. Savage, R. Anooshehpoor and A. Sheehan (2001). The 1992 Little Skull Mountain earthquake sequence, southern Nevada Test Site, Bull. Seism. Soc. Am., 91, 1595-1606.

Snelson, C. and 15 others (2003). Preliminary Results From SILVVER '03 - Seismic Investigations of the Las Vegas Valley: Evaluating Risk, Eos Trans. AGU, 84(46), Fall Meet. Suppl., Abstract S11D-0325, 2003

Springer, D., G. Pawloski, J. Ricca, R. Roher and D. Smith (2002). Seismic source summary for all U.S. below-surface nuclear explosions, Bull. Seism. Soc. Am., 92, 18061840.

Steidl, J., A. Tumarkin and R. Archuleta (1996). What is a reference site?, Bull. Seism. Soc. Am., 86, 1733-1748.

Su, F., J. Anderson, S. Ni and Y. Zeng (1998). Effect of site amplification and basin response on strong motion in Las Vegas, Nevada, Earthquake Spectra, 14, 357-376.

Tucker, B., J. King, D. Hatzfeld and I. Nersesov (1984). Observations of hard-rock site effects, Bull. Seism. Soc. Am., 74, 121-136.

Virieux, J. (1986). P-SV wave propagation in heterogeneous media: velocity-stress finite difference method, Geophysics, 51, 889-901.

Walter, W., K. Mayeda and H. Patton (1995). Phase and spectral ratio discrimination between NTS earthquakes and explosions. Part I: empirical observations, Bull. Seism. Soc. Am., 85, 1050-1067.

Wernicke, B., G. Axen and J. K. Snow (1988). Basin and Range extensional tectonics at the latitude of Las Vegas, Nevada, Geol. Soc. Am. Bull., 100, 1738-1757. 
Table 1. Event information for the NTS nuclear explosions used in this study (Springer et al., 2002).

\begin{tabular}{|c|c|c|c|c|c|c|c|c|c|}
\hline$\#$ & Name & Date & $\begin{array}{l}\text { Time } \\
\text { (UTC) }\end{array}$ & $\begin{array}{l}\text { Test } \\
\text { Area }\end{array}$ & Latitude & Longitude & $\begin{array}{l}\text { Depth } \\
\text { (meters) }\end{array}$ & Magnitude & $\begin{array}{l}\text { Yield } \\
\text { (kiloton) }\end{array}$ \\
\hline 1 & BOXCAR & 1968 Apr 26 & $15: 00: 00.07$ & Pahute & 37.295 & -116.457 & 1158 & - & 1300 \\
\hline 2 & HANDLEY & 1970 Mar 26 & 19:00:00.20 & Pahute & 37.300 & -116.535 & 1209 & - & $>1000$ \\
\hline 3 & MUENSTER & 1976 Jan 03 & 19:15:00.16 & Pahute & 37.297 & -116.334 & 1452 & - & $200-1000$ \\
\hline 4 & FONTINA & 1976 Feb 12 & $14: 45: 00.16$ & Pahute & 37.271 & -116.489 & 1219 & - & $200-1500$ \\
\hline 5 & JORNADA & $1982 \operatorname{Jan} 28$ & 16:00:00.10 & Yucca & 37.091 & -116.052 & 639 & 5.9 & 139 \\
\hline 6 & NEBBIOLO & 1982 Jun 24 & 14:15:00.09 & Pahute & 37.236 & -116.371 & 640 & 5.6 & $20-150$ \\
\hline 7 & TURQUOISE & 1983 Apr 14 & 19:05:00.12 & Yucca & 37.073 & -116.047 & 533 & 5.7 & $<150$ \\
\hline 8 & MUNDO & 1984 May 01 & 19:05:00.09 & Yucca & 37.106 & -116.023 & 566 & 5.3 & $20-150$ \\
\hline 9 & COTTAGE & 1985 Mar 23 & 18:30:00.08 & Yucca & 37.180 & -116.090 & 515 & 5.3 & $20-150$ \\
\hline 10 & GASCON & 1986 Nov 14 & 16:00:00.07 & Yucca & 37.100 & -116.049 & 593 & 5.8 & $20-150$ \\
\hline 11 & BODIE & 1986 Dec 13 & 17:50:05.08 & Pahute & 37.263 & -116.413 & 635 & 5.5 & $20-150$ \\
\hline 12 & TAHOKA & 1987 Aug 13 & 14:00:00.09 & Yucca & 37.061 & -116.046 & 639 & 5.9 & $20-150$ \\
\hline 13 & BARNWELL & 1989 Dec 08 & 15:00:00.09 & Pahute & 37.231 & -116.410 & 601 & 5.5 & $20-150$ \\
\hline
\end{tabular}

* Teleseismic $\mathrm{m}_{\mathrm{b}}$ from the International Seismological Centre (ISC) 


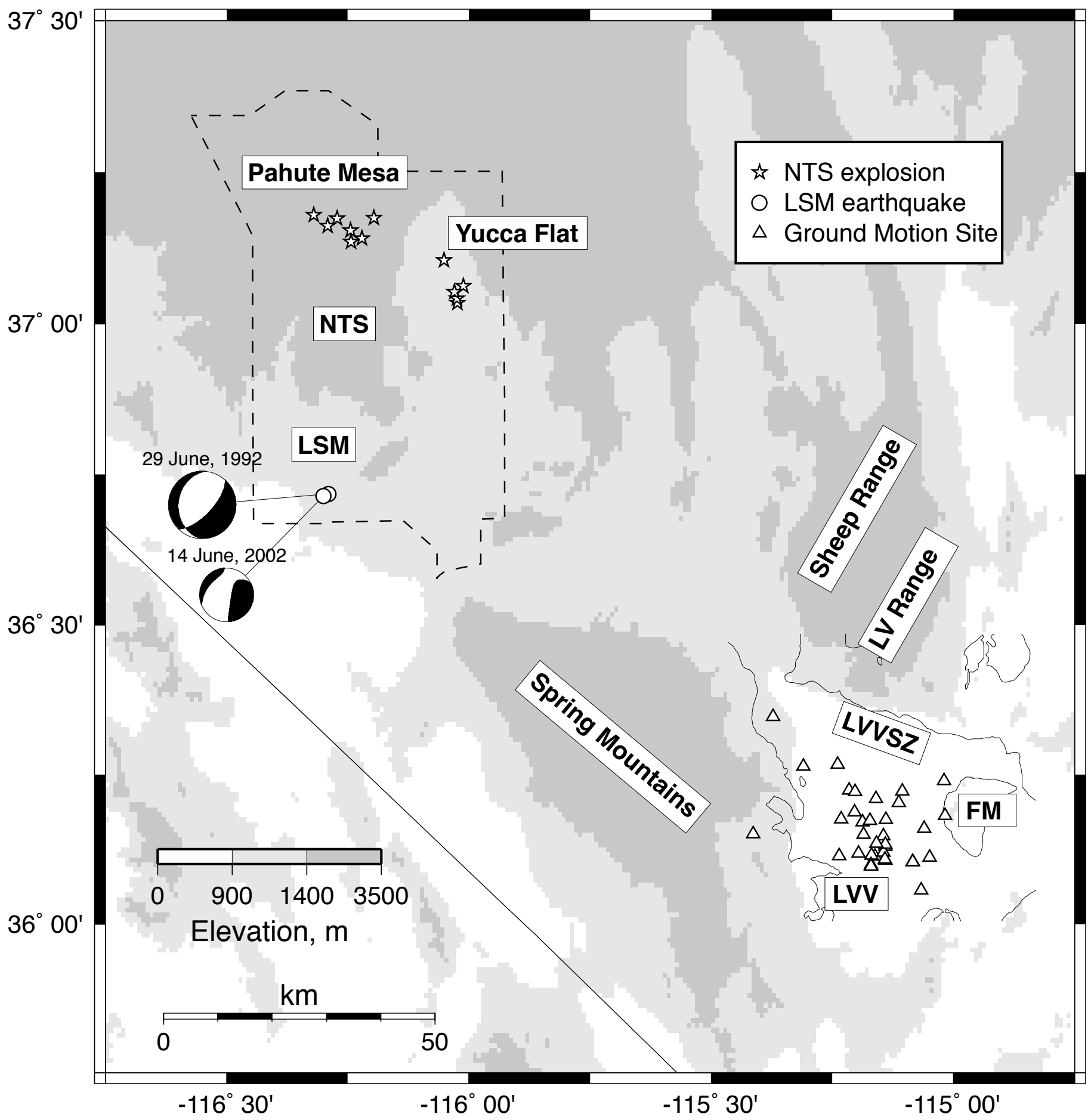

Figure 1. Map of southern Nevada showing Las Vegas Valley (LVV), the Nevada Test Site (NTS) and regional tectonic/geologic features (LVVSZ = LVV Shear Zone; FM = Frenchman Mountain). NTS nuclear explosions considered in this study are shown (stars). The Little Skull Mountain (LSM) main shock and aftershock are shown with double couple focal mechanism and moment tensor, respectively (Romanowicz et al., 1993; Dreger, http://www.seismo.berkeley.edu). Seismic stations from the BLUME network used in this study are shown as triangles. The basin/hard rock contact from Langenheim et al. (2001) is shown in LVV. 

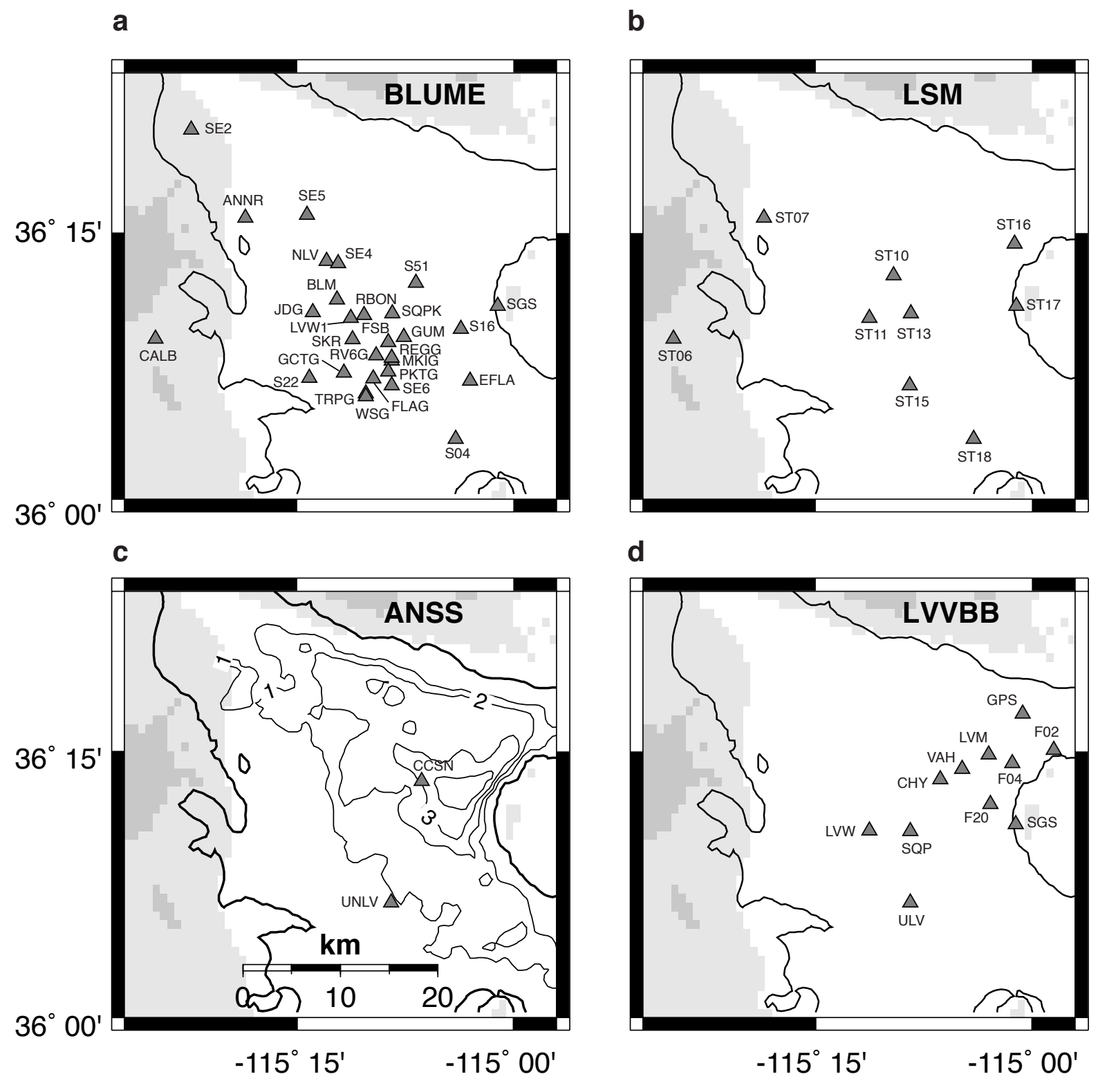

Figure 2. Map of Las Vegas Valley showing seismic stations from various networks used in this study (triangles): (a) BLUME; (b) LSM; (c) ANSS and (d) LVVBB. In (c), 1-km contours showing the depth to basement by Langenheim et al. (2001). 

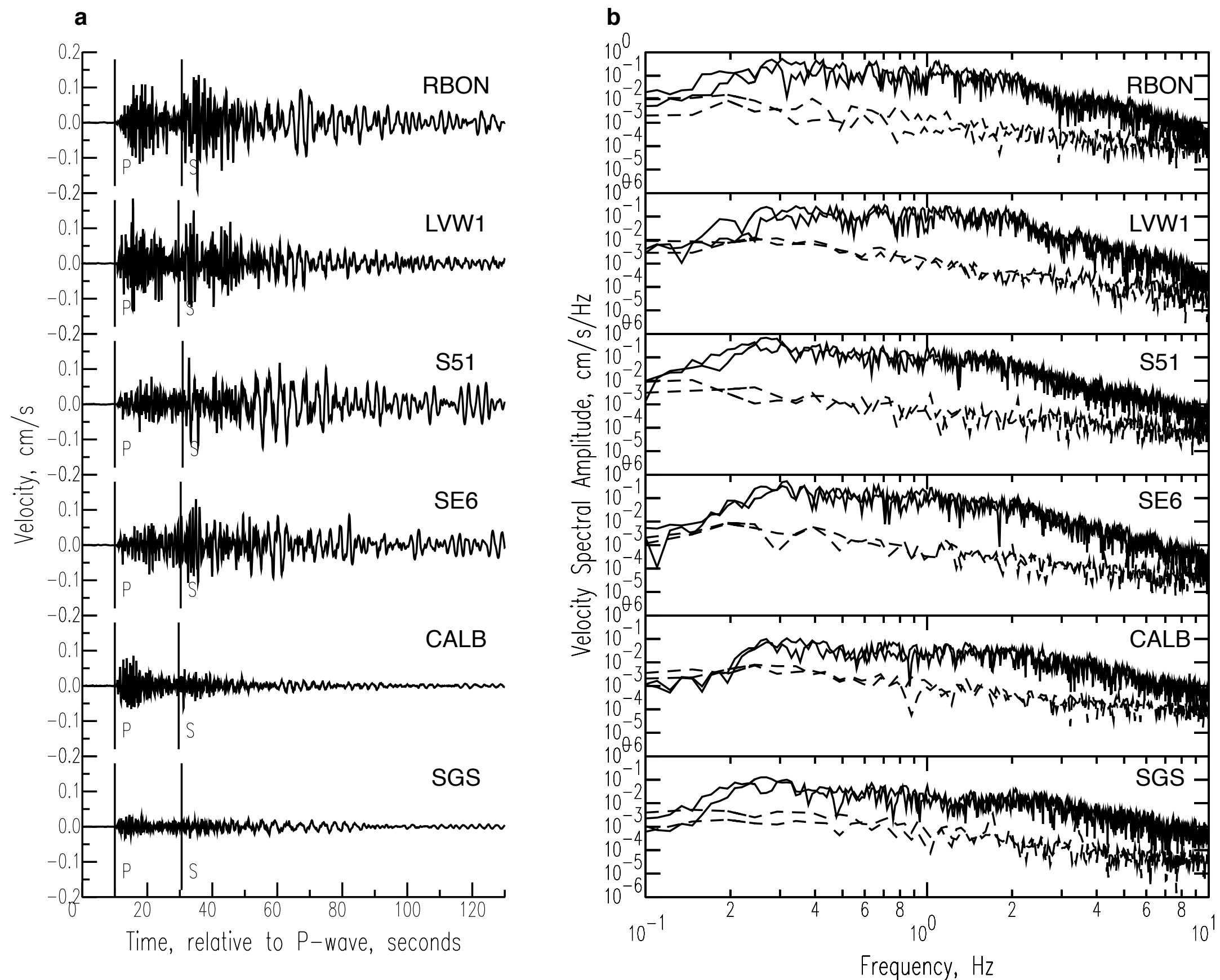

Figure 3. (a) North component velocity waveforms (0.1-10 Hz) for the BARNWELL nuclear test at a few sites in LVV. (b) Horizontal component velocity amplitude (solid) and noise (dashed) spectra for the waveforms shown in (a). 


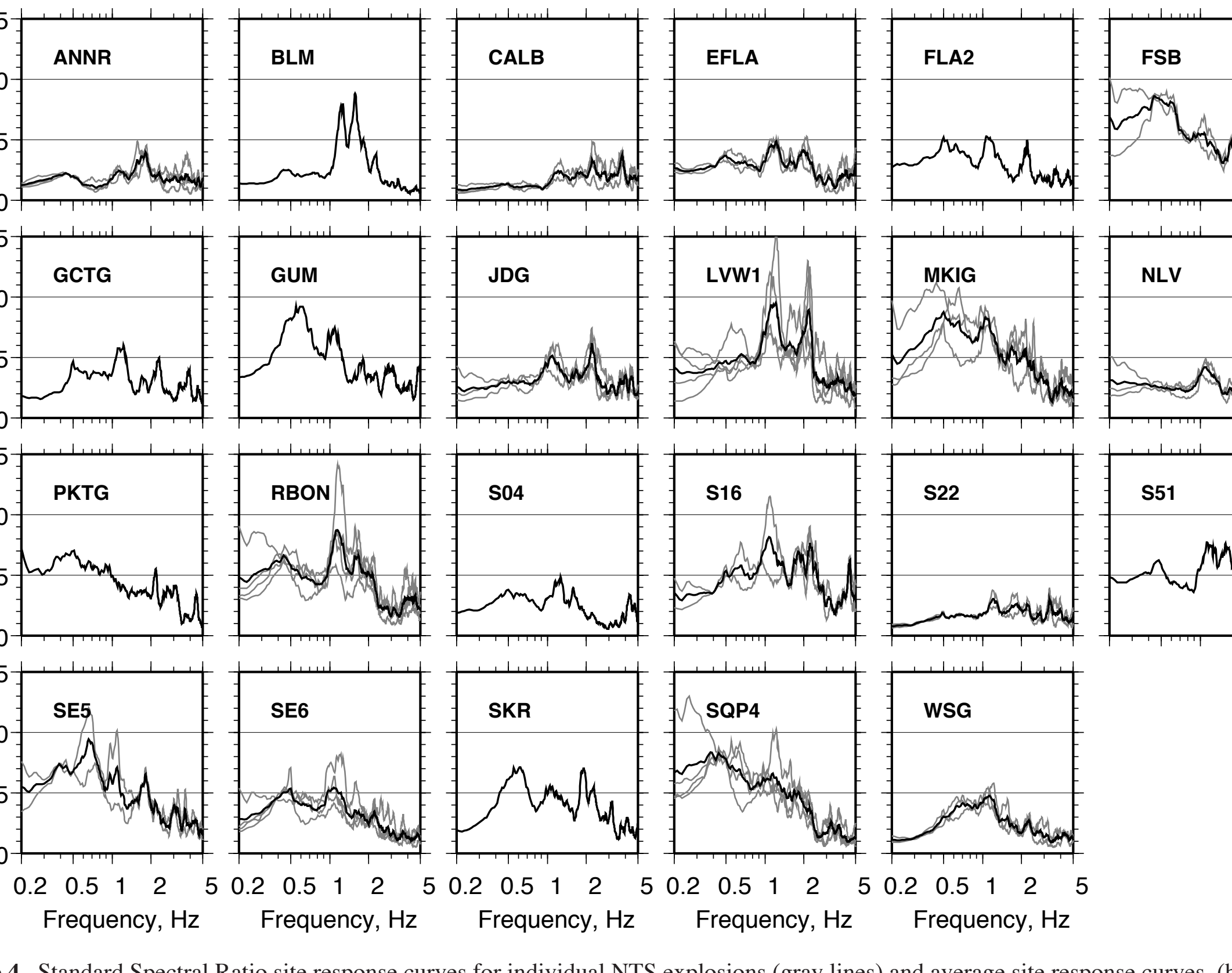

4. Standard Spectral Ratio site response curves for individual NTS explosions (gray lines) and average site response curves ( $\mathrm{b}$ it twenty three sites in Las Vegas Valley. 
A
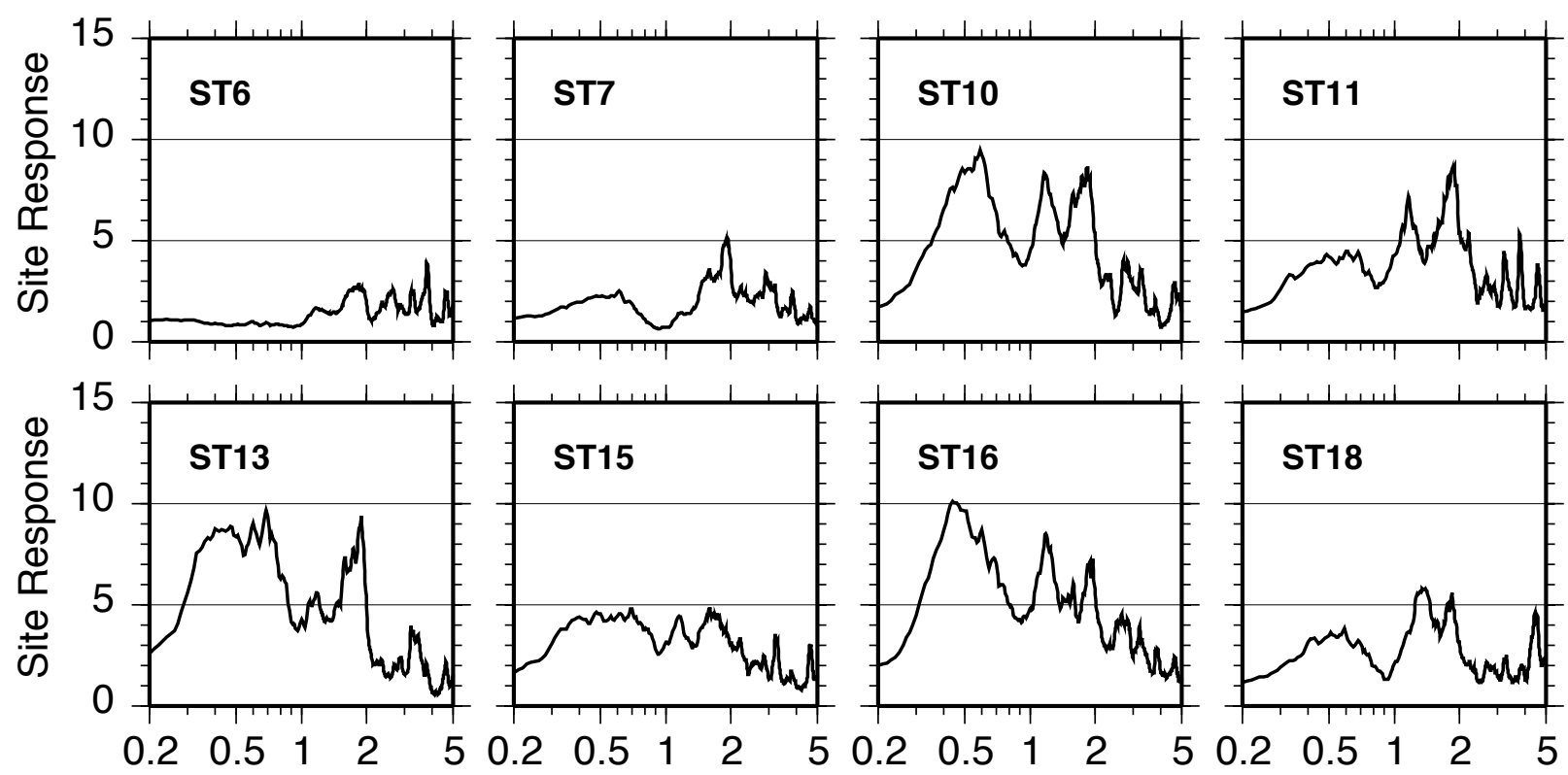

Frequency, $\mathrm{Hz} \quad$ Frequency, $\mathrm{Hz} \quad$ Frequency, $\mathrm{Hz} \quad$ Frequency, $\mathrm{Hz}$

B
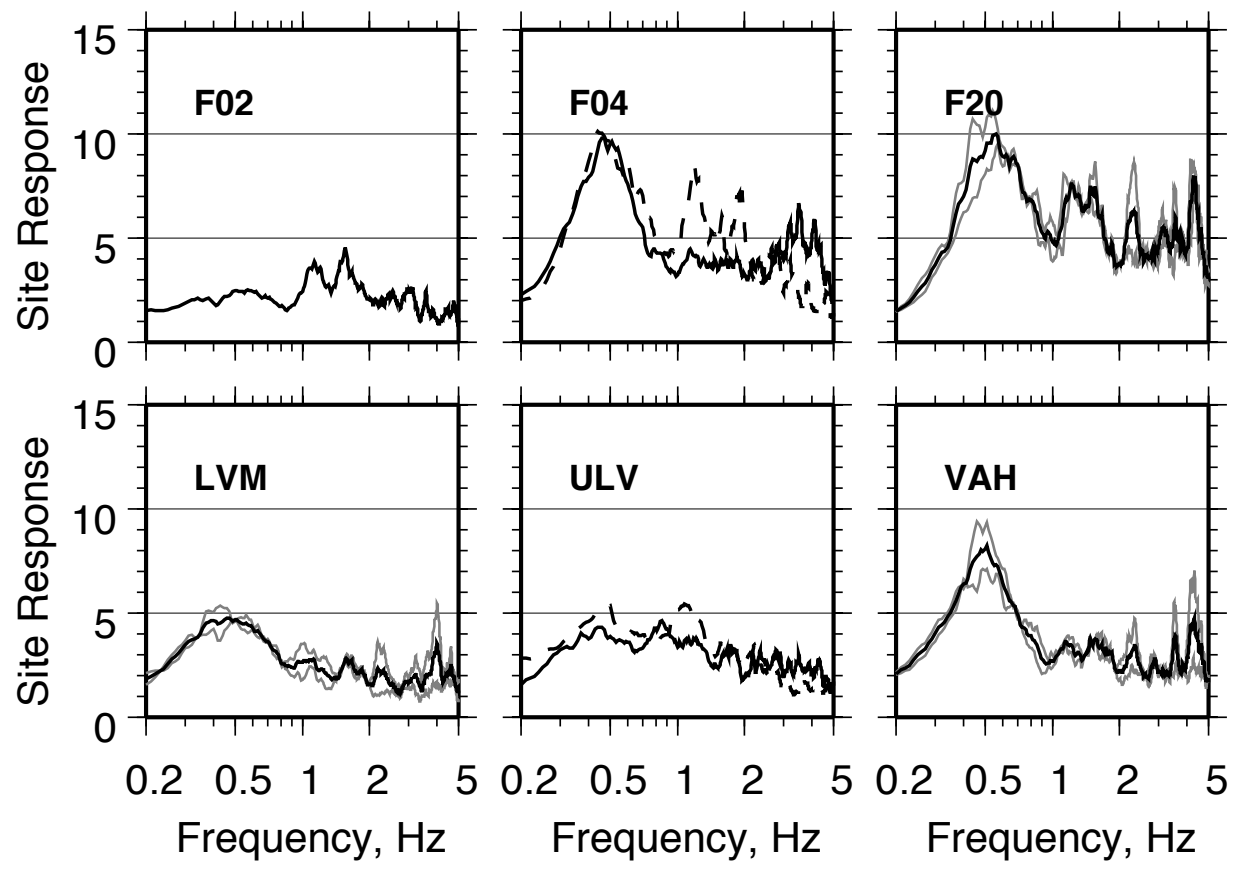

Frequency, $\mathrm{Hz}$

Frequency, $\mathrm{Hz}$

Figure 5. Standard Spectral Ratio site response curves for the (A) Little Skull Mountain (LSM) earthquake and (B) Las Vegas Valley Broadband (LVVBB) Deployment . In (B) individual curves from regional earthquakes are shown as gray lines, average curves ar black lines. For comparison at sites F04 and ULV we show the curves for the LSM data at co-located sites ST10 and ST15, respectively (dashed lines). 

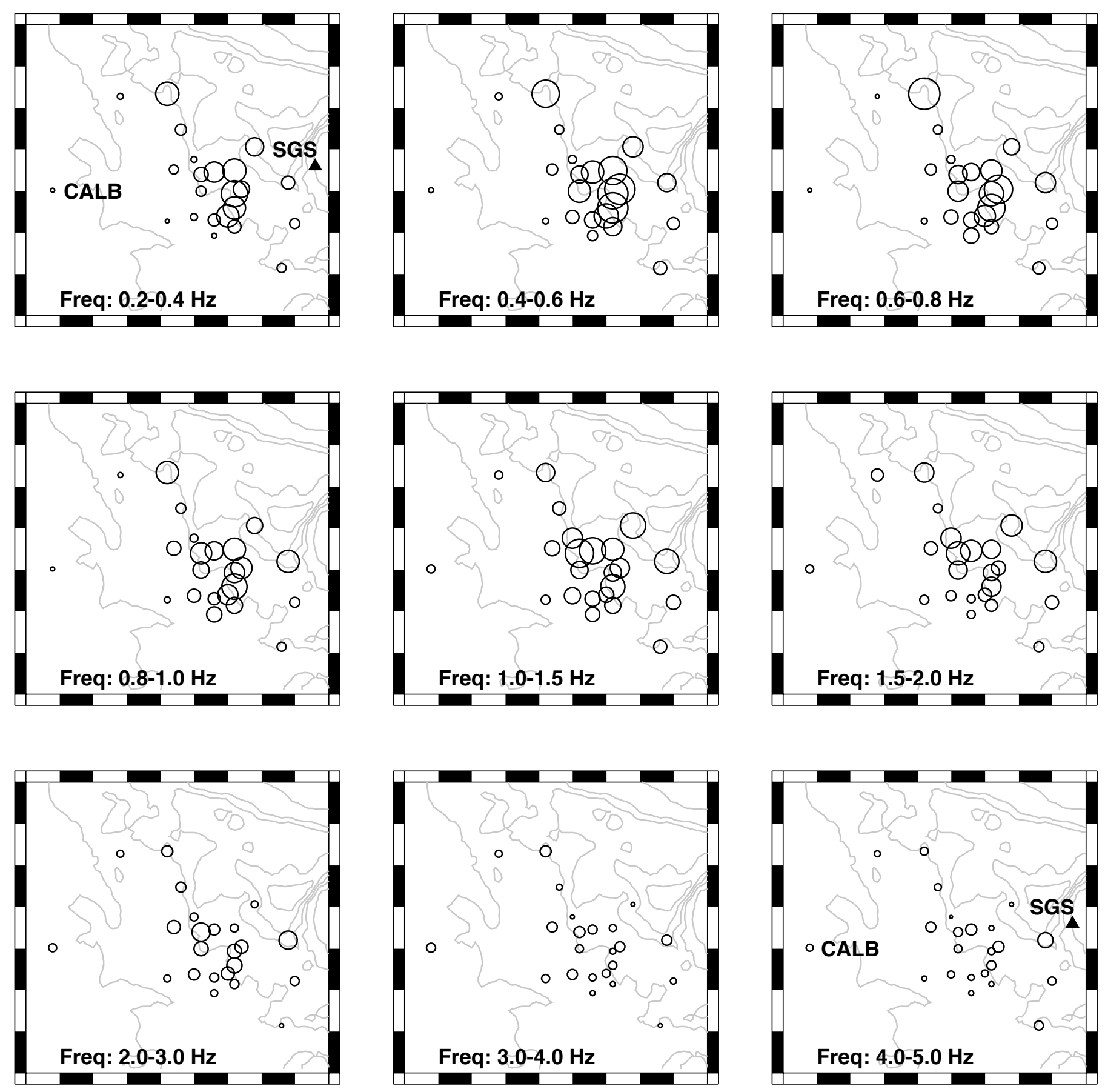

KEY

$\begin{array}{llll}1.0 & 2.0 & 4.0 & 8.0\end{array}$

Figure 6 Maps of average site response relative to SGS for sites in Las Vaegas Valley (circles). Also shown is are 1-km basin depth contours from Langenheim et al. (2001). 

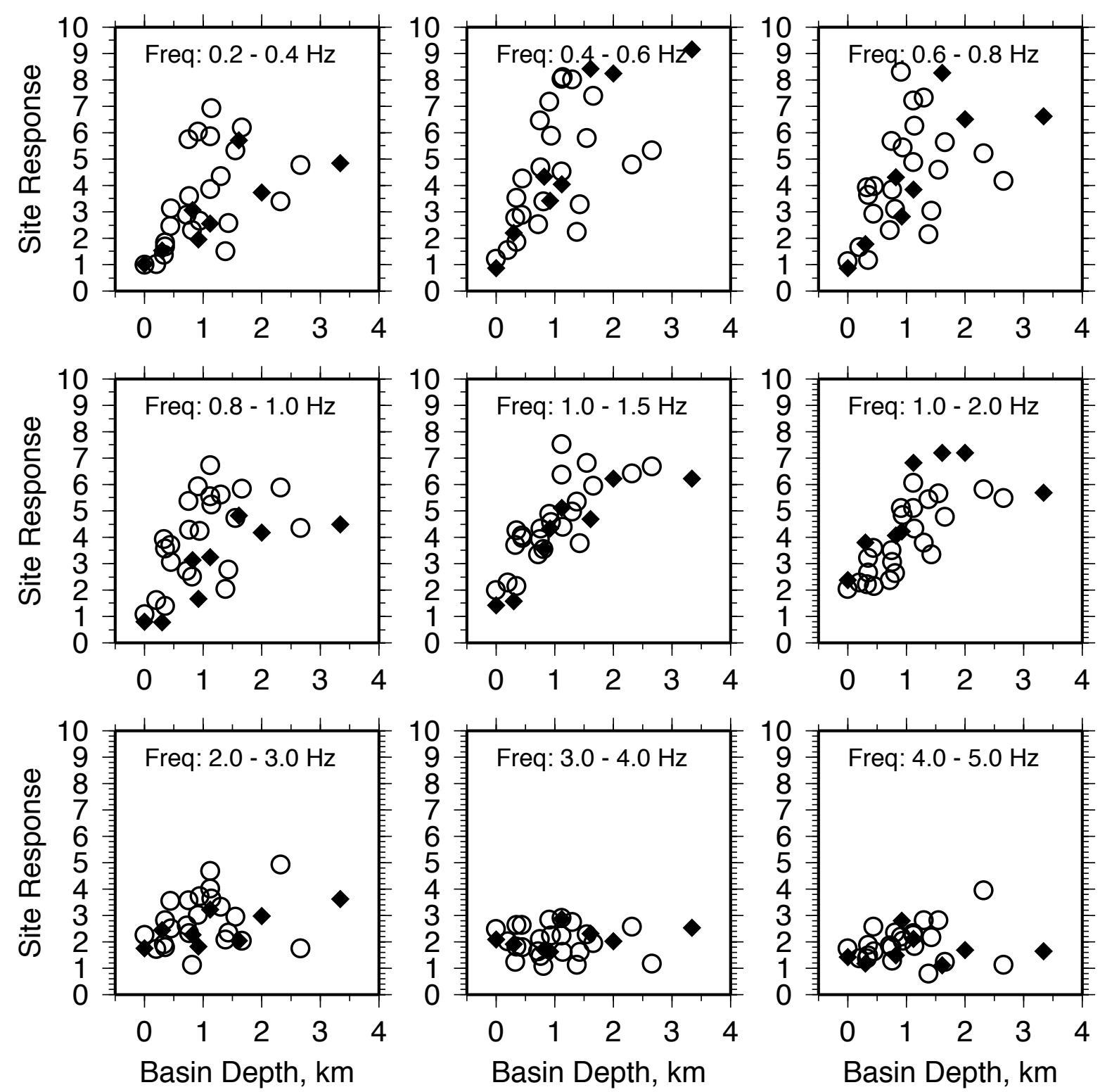

Figure 7. Average site response versus basin depth at sites in Las Vegas Valley for NTS explosions (open circles) and the Little Skull Mountain earthquake (solid diamonds). 


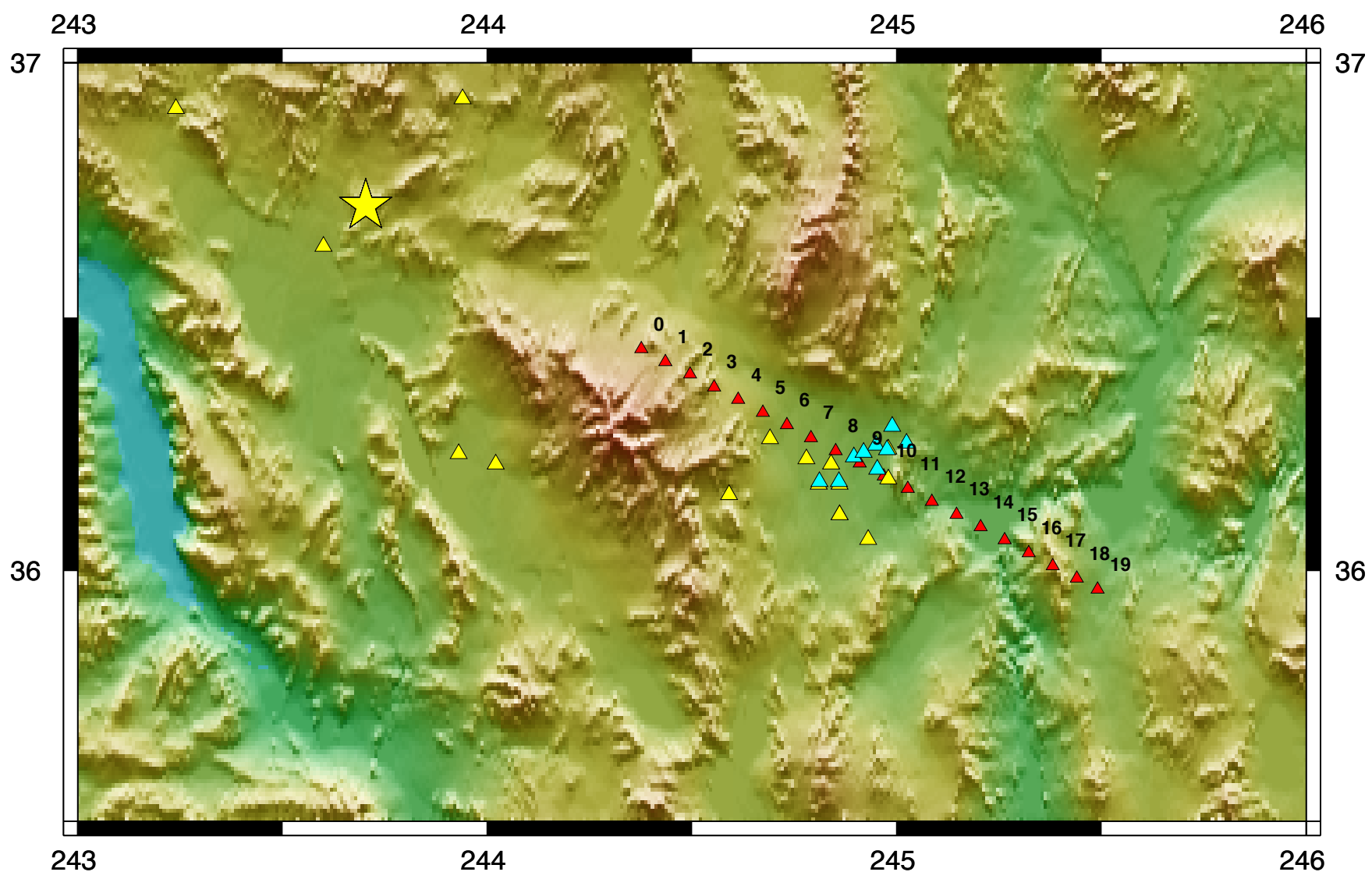

Figure 8. Map of southern Nevada showing the Little Skull Mountain earthquake (LSM), strong motion stations (yellow triangles) and design of our synthetic experiments (red triangles). 


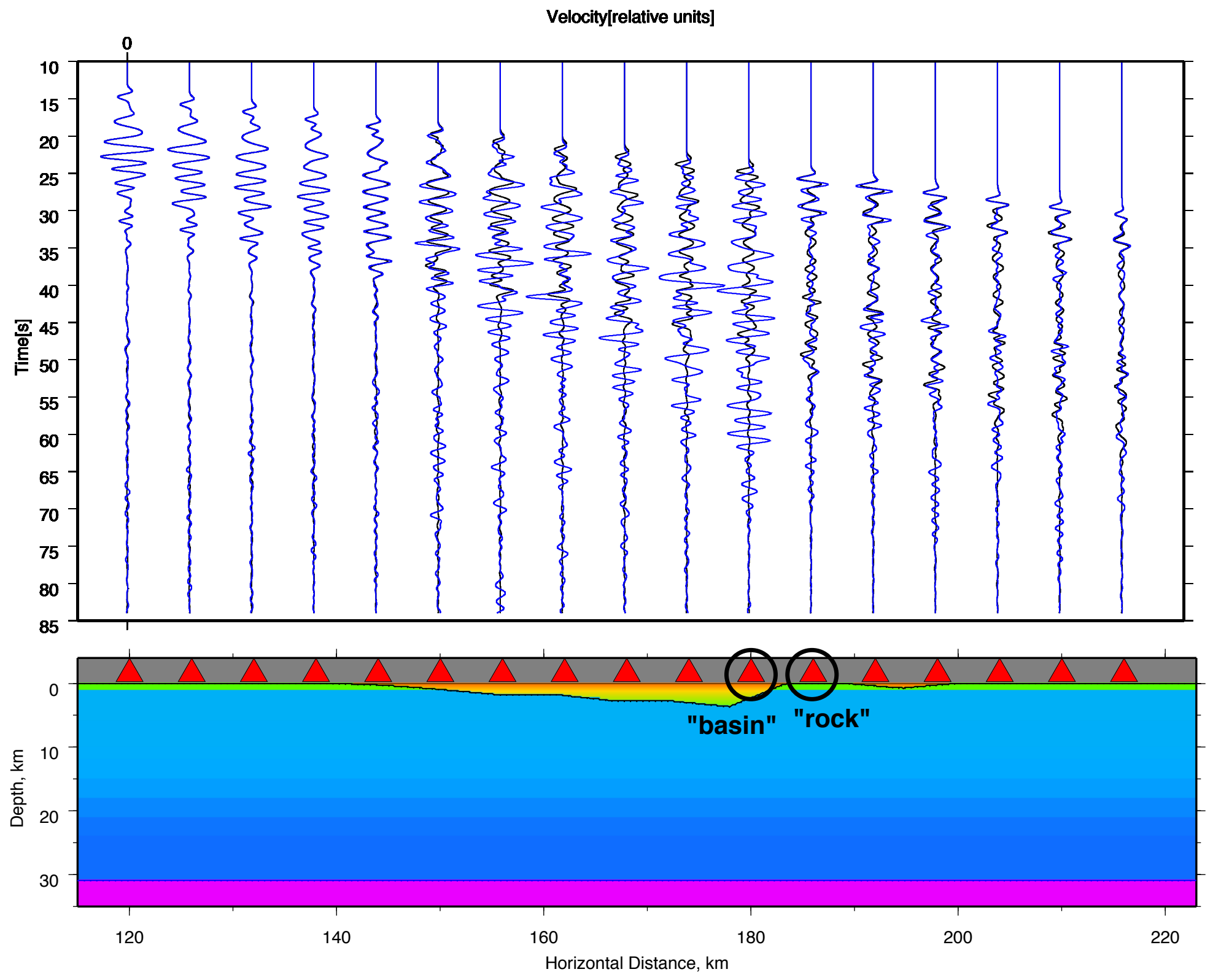

Figure 9. (A) Horizontal component synthetic waveforms for the plane-layered background model (black) and the 2D model with basin structure (blue). (B) Cross-section of the 2D model showing color-coded shear-wave velocities. Stations where synthetic seismograms are output are shown as red triangles. 

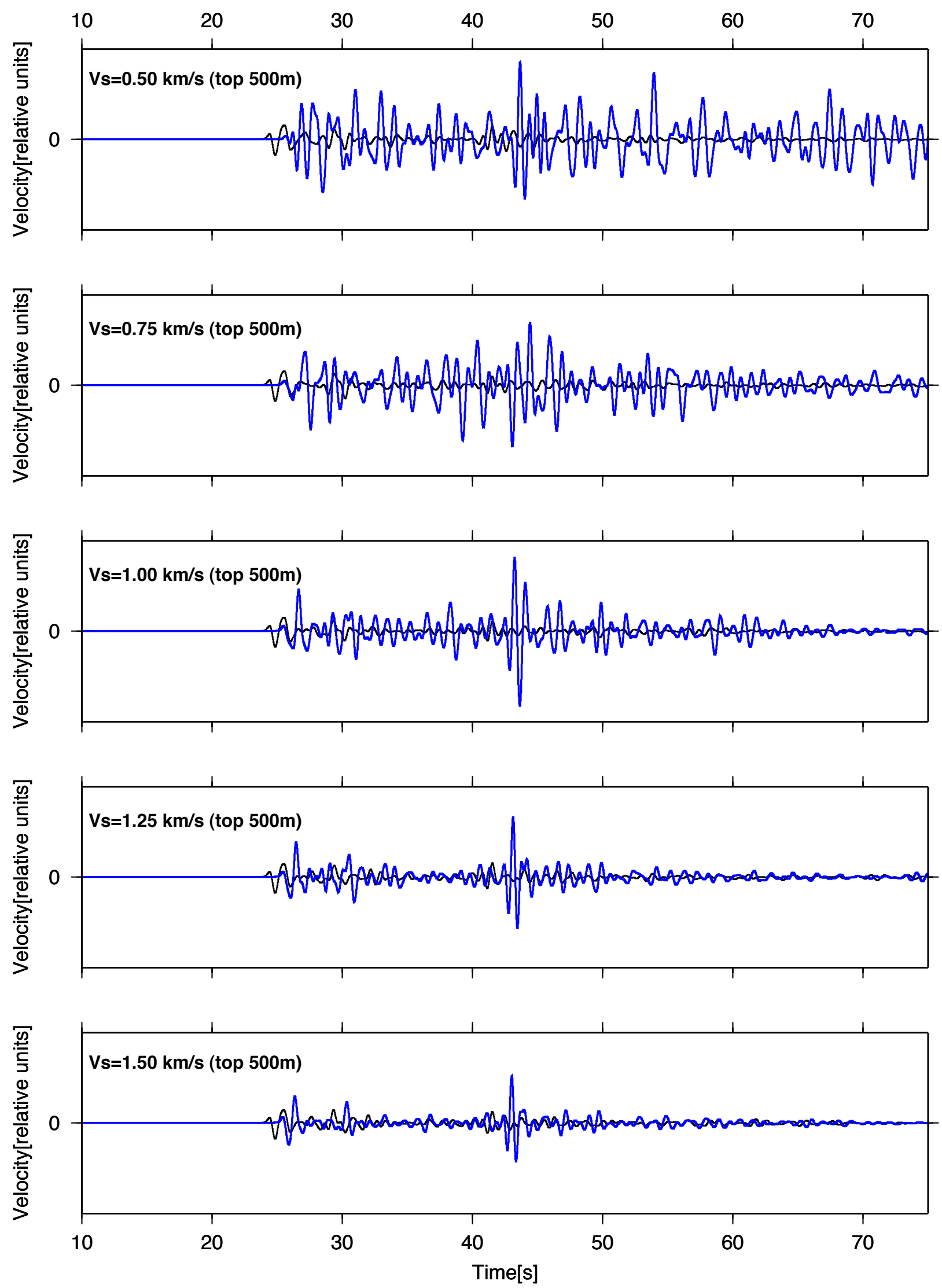

Figure 10. Horizontal component waveforms for the "basin" (blue) and "rock" (black) sites for synthetic experiments illustrated in Figure 9. Each panel shows the results using different shallow shear velocities within the upper $250 \mathrm{~m}$ of the basin. These shear velocities range from $500-1500 \mathrm{~m} / \mathrm{s}$. 

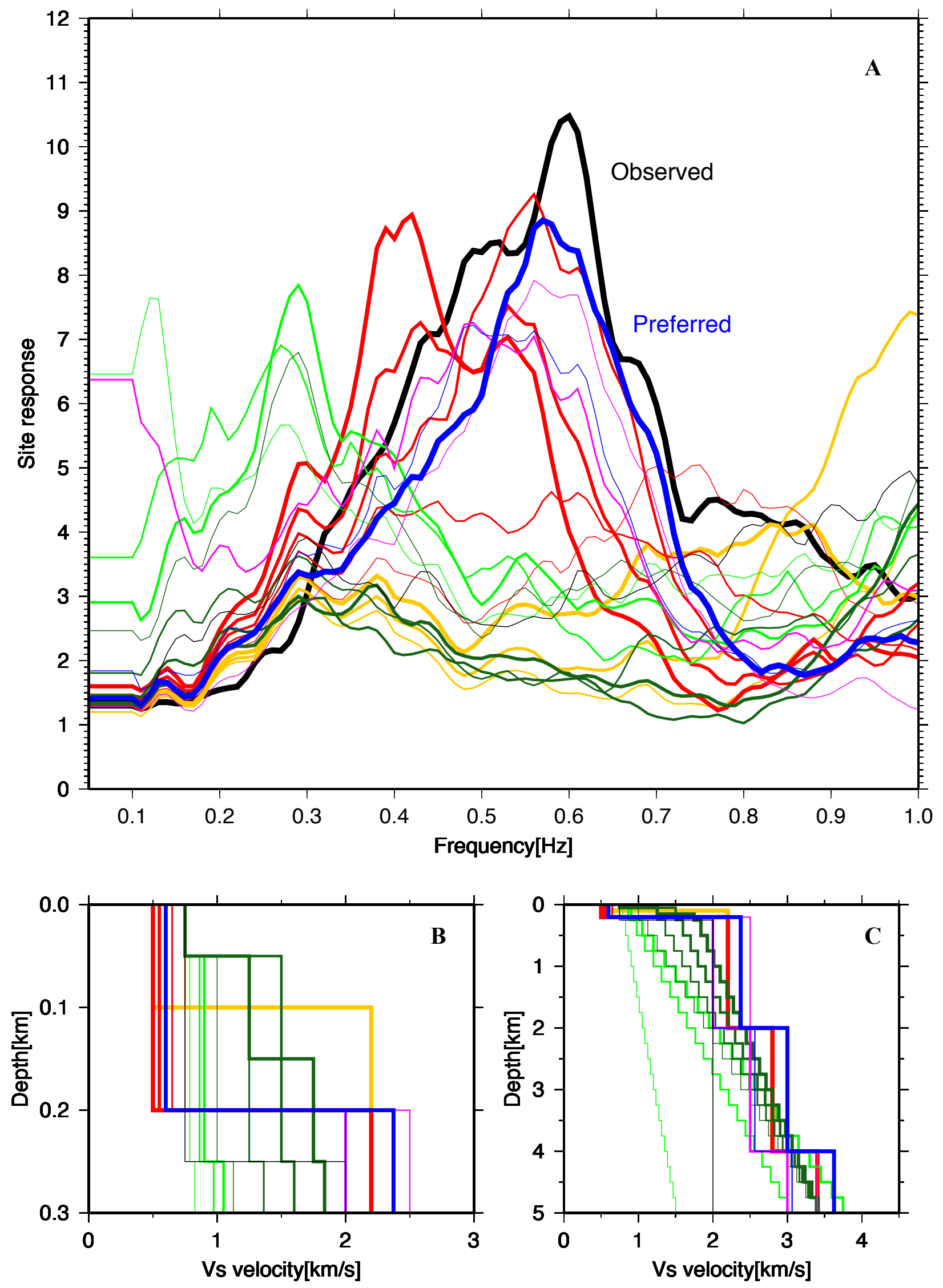

Figure 11. (A) Observed (thick black line) and synthetic (colored) site response curves for a wide range of basin velocity models. Site response curves are color-coded to their basin velocity models shown in (B) and (C). (B) and (C) show the basin velocity models for shallow and basin-scale depths, respectively. Our preferred model is shown in blue. 